\title{
A Botanical Association Involving Elizabeth Pym, Peter Collinson, Sir Hans Sloane, and Admiral Sir Charles Wager
}

\author{
Fernando E. Vega ${ }^{a}$ \\ a14609 Pebblestone Dr., Silver Spring, Maryland 20905, USA. E-mail: trainofstories@gmail.com; ORCID: \\ http://orcid.org/0000-0001-8103-5640
}

(C) The Author, 2021

\begin{tabular}{ll}
\hline ABSTRACT & ARTICLE HISTORY \\
Elizabeth Pym wrote a letter in 1742 from the island of Nevis, in the & Received: 3-01-2021 \\
Caribbean Sea, to Peter Collinson in London, describing various botanical & Revised: 15-04-2021 \\
samples she was sending him, including two coffee plants. The letter was & Accepted: 3-06-2021 \\
found inside Volume II of Sir Hans Sloane's "A Voyage to the Islands & \\
Madera ..." housed at Oak Spring Garden Library in Virginia. Collinson & KEYWORDS \\
received both volumes as gifts, with Volume I inscribed to him by Admiral & Botany \\
Sir Charles Wager and Volume II inscribed by Sloane. The letter serves as & Botanical specimens \\
a rare example documenting the collection of botanical specimens by a & Mellon \\
woman in the New World. & Nevis \\
& Oak Spring Garden \\
& Library \\
\hline
\end{tabular}

\section{Introduction}

A letter by Elizabeth Pym (died ca. 1777), a resident of the British colony of Nevis ${ }^{1}$ in the Caribbean Sea, was written in June 1742 and mailed to Peter Collinson (1694-1768) in London. Collinson was a Quaker and a textile merchant who had a deep interest in nature. He had many contacts around the world who sent him natural history specimens, predominantly plants. Mrs. Pym's letter (Fig. 1; transcribed below), which describes the botanical samples (mostly seeds) she sent to Collinson, was found inserted in Volume II of Collinson's copy of Sir Hans Sloane's (1660-1753) two-volume set entitled "A Voyage to the Islands Madera ..." (Sloane 1707, 1725). Both volumes, housed at Oak Spring Garden Library in Upperville, Virginia, were gifts from Sloane and Admiral Sir Charles Wager (1666-1743) to Collinson.

\footnotetext{
1 Alexander Hamilton (ca. 1757-1804), a Founding Father of the United States, was born in Nevis.
}

This botanical association is interesting as it involves three important figures of London in the $18^{\text {th }}$ Century. First and foremost is Sir Hans Sloane, who succeeded Sir Isaac Newton as President of the Royal Society from 1727 to 1741. Sloane's collection of books, manuscripts, and specimens became the foundation for establishing the British Museum. Peter Collinson is well known for the importation of plants to England. One of his most notable collectors was John Bartram (1699-1777) in Pennsylvania, a Quaker and a self-taught botanist (Armstrong 2002). Collinson introduced Benjamin Franklin (17061790) to electrical experiments conducted in Germany and Franklin shared the results of his now famous investigations on electricity in various letters to Collinson (Franklin 1751). Finally, Admiral Wager had a long career in the British Royal Navy and served as First Lord of the Admiralty. 
The first volume is inscribed "November the $14^{\text {th }}$ 1740, I give the Book to my friend $\mathrm{M}^{\mathrm{r}}$ Peter Collinson, Chas. Wager." Volume II is inscribed by Sloane as follows: "Nov. 13, 1740. This is my gift to my very good $\&$ very much esteemed friend $\mathrm{M}^{\mathrm{r}}$. Peter Collinson, Hans Sloane.” In an undated letter from Collinson to Sloane, dated to "circa 1740" by Armstrong (2002), Collinson writes, "Pray, is the Dumb Cane figured In your History and under what Title? I have the Second part which Sr Charles Wager gave Mee, but I have not your first part." Collinson is referring to Sloane's "A Voyage to the Islands Madera ..." and dumb cane (Dieffenbachia; Araceae) is mentioned in page 168 of Volume I. It would appear that Collinson mistook Wager's gift as Volume II, thus not realizing he already had Volume 1, and that Sloane's gift (Vol. II) had not yet reached Collinson.

Three bookplates are affixed to the paste-down endpaper of each volume, in the following order, from top to bottom: (1) A circular red bookplate that reads "Oak Spring Paul Mellon"; (2) John Cator's (1728-1806) bookplate, with his coat of arms which includes the Latin phrase "nihil sine labor" ("nothing without labor"); and (3) A rectangular bookplate that reads " $R$ M Oak Spring Garden Library", with the "R M" standing for "Rachel Mellon".

John Cator, a wealthy Quaker, was married to Collinson's daughter, Mary (1733-1804), and he probably inherited the two volumes from his father-in-law. There is a large gap in the provenance; however, Sloane's two-volume set was purchased by Paul Mellon on September 27, 1962, from Lionel \& Philip Robinson Ltd., antiquarian booksellers in London. Paul (19071999) and Rachel (1910-2014) Mellon were collectors of art and rare books, with Mrs. Mellon having a special interest in rare botanical books. Their book collection is housed at Oak Spring Garden Library, in Upperville, Virginia. Mrs. Mellon designed the Rose Garden at the White House, and together with her husband, donated over 1000 paintings to the National Gallery of Art in Washington DC.

Elizabeth Pym's (née Butler) birthplace or birthyear is not known and what follows was

\footnotetext{
${ }^{2}$ Added in Collinson's hand.

3 Thomas or Johh Hooke, Col. Thomas Butler's brothers-in-law; The National Archives, Kew,
}

gathered from Oliver (1919), unless otherwise specified. She was the daughter of Col. Thomas Butler (ca. 1687-1744), "London merchant, agent for Nevis" (Legacies of British Slave-ownership 2021a). In 1707-1708, Col. Butler had 26 male and 24 female slaves in Nevis (Oliver 1894). Elizabeth married the Nevisian Thomas Pym (1701-1743) in 1730. Mr. Pym's last will, written in London on 16 December 1738 (The National Archives 2021), specified that Elizabeth would inherit all his plantations in Nevis, including "the Negroes slaves", although the three plantations he owned, encompassing 486 acres, had been mortgaged on 14 December 1738 to Elizabeth's father for $£ 7330$. If Elizabeth was with him in London in 1738, she was back in Nevis by 1742 , as her letter to Collinson indicates. After Pym's death in 1743, Elizabeth remarried. Her second husband was John Dasent (d. 1754), and their place of residence is unknown. Elizabeth's last will was written in Little Moorfields, London in 1776 (Legacies of British Slave-ownership 2021b). She died ca. 1777 and was presumably buried in the Butler vault at St. Giles Church, in Camberwell, in the London Borough of Southwark.

\section{Transcription of Elizabeth Pym's letter}

$$
\text { nevis July } y^{\mathrm{e}} 151742
$$

\section{$\mathrm{M}^{\mathrm{r} .}$ Collinson}

answerd October $201742^{2}$

I wrot to you, some time ago, by $\mathrm{Cap}^{t}$ martin, which I hope, you have receiv ${ }^{\mathrm{d}}$, and I now, send you, by $\mathrm{M}^{\mathrm{r}}$ Butler Symonds, a box of seeds, which I hope, you will get safe, and prove god, but I must, desire you, to send me, the box, that the rest, is put up in, back again, and Likewise, to fill it up, with Little boxe's, of several size's, to put seeds, in

again, for you, for thay are, very hard, to be got here, which makes me, so troublesome, to you, in desiring you, to send them me, if you will be so good, to give them, to my mother, or $\mathrm{M}^{\mathrm{r}}$ Hooke ${ }^{3}$, thay will take care, to send them, to me, $\mathrm{M}^{\mathrm{r}} \mathrm{Pym}$,

England, Prerogative court of Canterbury and related probate jurisdictions: will registers; Class: PROB11; Piece: 733. 
and miss Butler, Joyn's with me, in kind serve, to you, good, spouse, and family, I am

$$
\begin{array}{r}
S^{\mathrm{r}} \text {, your friend, \& serv }{ }^{\mathrm{t}} \text {, to Comm }{ }^{\mathrm{d}}:, \\
\text { Eliz }^{\mathrm{a}} \text { : Pym }
\end{array}
$$

a List of seeds, now sent, of the fruit seeds, watermelion seeds, Tamerin seeds, mammy apple, or nubed apple, seeds, orange seeds, Bell apple seeds, sour sop seeds, shadock's seeds, Locust seeds, custard apple seeds, Pingwin seeds, a mammy sea port seed, spanish Plum, or Red Plum, seeds, yallow Plum seeds, cherry stones, Lemon seeds, Burgemott Lemon seeds, Lime seeds, Lemaw seeds, Lemaws, is as fine souring, as a Lemon, and as Large, as a shadock, of the wild Plant seeds Goat pepper seeds, Bell Pepper seeds, sorrel seeds, Sorrel, the flowers stew ${ }^{\mathrm{d}}$, makes pritty tarts, or boil ${ }^{\mathrm{d}}$ in water, and mixt after with sirrup, makes an Exceeding pleasant drink, snake bush, is of no use, but the beads, is pritty, Cuckow bead bush, is Exceeding good, for a cold, or cough, Either made in a Tea, or a sirrup, and the beads, is a purge, and vomit, vervine, and stinking weed is both of the same nature, the Juce is a good purge and good to destroy worms, in children, and good for dropsical people, and the Leave's boil ${ }^{\mathrm{d}}$ in a bath, is good for an ulcer, or swelling, Royal cushaw, or spanish cushaw, is a pritty tree and makes an Exceeding good, fence, white honesty on use, only for a rarity, Red honesty, is a pritty flower, and some say, that the root is, the Right Jollop, Thistle seeds, is a good vomitt, and is an Exceeding, fine thing, for the flux, and is to be giving acording to the age of a person, and is to be giving, from one thimble full, to Eight, thimble fulls, not to Exceed Eight, to a strong, Grown Person, it must be brused, and mixt, with honey, or sirrup, and work ${ }^{\mathrm{d}}$ off with warm water, and the milk, that comes out of the bush, is good for to cure, a wound, or an ulcer, or the Leaves boild., in a bath, is good for a swelling, or an ulcer, Itchey weed, makes a good ointment, for the Itch, the Juce boild., with brimstone, and salt butter, agnus caster seeds, six or seven, of them, is a good purge, and vomit, bruised an mixt, with honey, and the seeds, makes a fine oyl, good for many things, it is a vomit, and good to rub, the joints with, for ach's, or sprains, or swellings, or the Leaves rosted, and put hot, is good Likewise, Gods Blessing, the bush brus ${ }^{\mathrm{d}}$ and put to the soals, of the feet, and to the rists, is very good for a fever, and to rub the Joynts, with it, and the roots brus ${ }^{\mathrm{d}}$, and steep ${ }^{\mathrm{d} .}$ in water, to rub the nose, and temples, with it, Likewise, for the fever, and the Juce is good for worm's, one spoonfull, for a child, of the Juce, it is a vomit, and purge both, some pretend to say, that it is, the right Indian root, but I cant tell, if it is, or not, Jobs tears is of n[ ]se, but I send them to plant, for a Rarity, sencitive, the roots, and Leaves boil ${ }^{\mathrm{d}}$, with water, and sweetn ${ }^{\mathrm{d}}$ and Drank a deal of it, will Expell, any poison, worm grass, the bush boil ${ }^{\mathrm{d}}$, with water, and sweetned, and Drank three nights, at going to rest, and at the full of the moon, is a fine thing, to destroy worm's, provided, it is prepared right, but if it is boil ${ }^{\mathrm{d}}$ to strong, it will kill, any one, for it is of the opium kind, a handful of the bush, will boil, several pints, of the drink, and a half pint, of it, at a time, is a full quantity, for a grown person.

\section{Sideways section in letter (see Fig. 1).}

Devils Bitt, is a fine sweat, boil ${ }^{\mathrm{d}}$ with water, the roots, and sweetned, and drink, a large quantity of it warm, at going to rest, and it is a fine thing for a fever, and to drink it, in the nature, of sage Tea, wild sage, the roots, makes a good Physic drink, and the Leaves and flowers, a Tea, but it purges, a Little, [ ]lk cotten, is not of much use, the cotten is soft, and silky, and the Leaves, is some times, made in a Tea, and giving, in these parts, for the small pox, yours [ ] before, E P since $y^{\mathrm{e}}$ above $\mathrm{M}^{\mathrm{r}}$ Symonds, was disapointed, of his passage, in Cap $^{t}$ Dewer, but your box of seeds, went in Dewer, who sail ${ }^{\mathrm{d}}$ three weeks [ ] to demand, your box of Cap ${ }^{t}$ Dewer, yours E Pym and, I now send you, two coffee trees, in a box, by Capt. Moone,

The following text in Elizabeth's letter has been encircled in ink, presumably by Collinson: "sencitive, the roots, and Leaves, boil", with water, and sweetn ${ }^{\mathrm{d}}$ and Drank a deal of it, will Expell, any poison," which suggests he found this information to be valuable. 


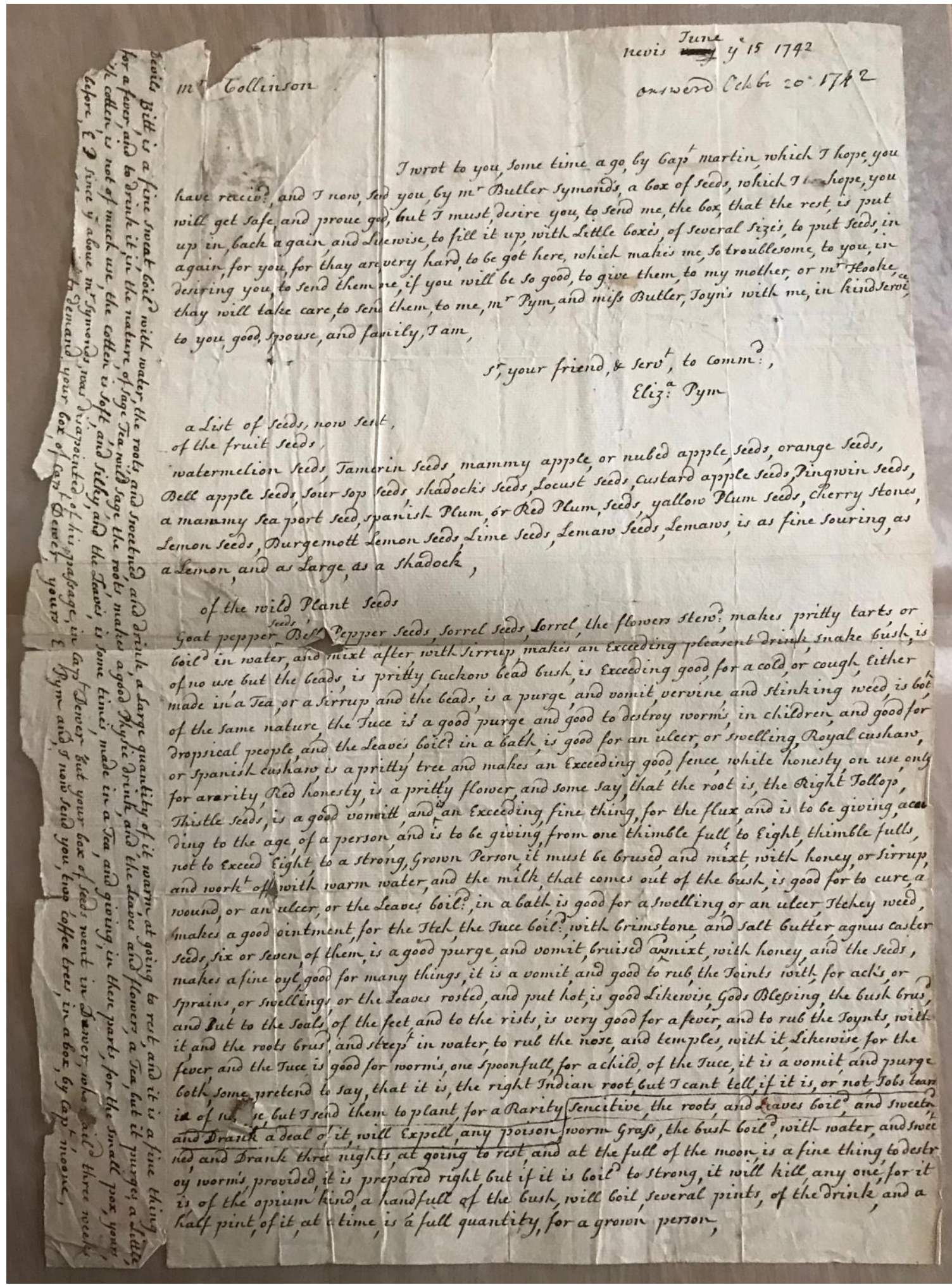

Figure 1. Elizabeth Pym's 15 June 1742 letter to Peter Collinson. Photograph courtesy of Nancy Collins (Oak Spring Garden Library, Upperville, VA, USA). 


\section{Discussion}

Elizabeth wrote to Collinson at least three times: (1) In the opening of her letter, she writes "I wrote to you, some time a go, by Cap ${ }^{t}$ martin"; (2) the present letter, dated 15 June 1742; and (3) the verso of the present letter has a note in Collinson's hand that reads as follows: "Mrs Pyms Letter containing the Vertues \& uses of plants growing in Nevis Writt again Decem 20 1742". It is not known whether Elizabeth and Collinson ever met in person, but it is clear that members of her family in London were acquainted with Collinson based on her asking him to return the little boxes in which she had placed seeds, i.e., "to give them, to my mother, or $\mathrm{M}^{\mathrm{r}}$ Hooke." Her family in Nevis was also familiar with Collinson and his family: " $\mathrm{M}^{\mathrm{r}}$ Pym, and miss Butler, Joyn's with me, in kind serve, to you, good, spouse, and family." It is interesting to find that a subscriber to Maittaire's (1732) book on ancient marbles is listed as "Mistress Elizabeth Pym", although it is impossible to tell for certain if the subscriber is the author of the letter to Collinson.

Elizabeth Pym was a remarkable woman for that time period, with homes in London and the Caribbean, and who was knowledgeable about the "vertues and uses of plants." The fact that a woman was shipping botanical material including two coffee trees - and medical recipes to the famous Collinson is noteworthy, as it was usually men who did the collecting. For instance, Carl Linnaeus arranged for 17 of his students, whom he referred to as his apostles, to travel overseas to collect botanical specimens for him; all of them were males (Blunt 1971). The London apothecary James Petiver (c. 1665 - c. 1718) had a significant network of collectors of natural history specimens and out of 118 people acknowledged in Petiver's Musei Petiveriani Centuria (published between 1695-1703 in six parts), six were women (Coulton 2020). We have only found one more female correspondent, i.e., Jane Colden (1724-1766), who sent plants to Collinson (Darlington 1849). Elizabeth Pym's letter documents her participation in the exchange of botanical material in the 1700's.

\section{Acknowledgements}

I am grateful to Tony Willis, Nancy Collins, and Kimberley Fisher at Oak Spring Garden Library (Upperville, Virginia), for their assistance and friendship, and to Isabelle Charmantier, Wendy S. Higgins, George Poinar, and Sarah Emche for comments on a previous version of this manuscript. Special thanks to Nancy Collins for Figure 1.

\section{Conflict of interest statement}

The authors declare no conflict of interest.

\section{References}

Armstrong, A. W. (2002). "Forget not mee \& my garden ..." Selected letters 1725-1768 of Peter Collinson, F.R.S. Memoirs of the American Philosophical Society, 241, 1300.

Blunt, W. (1971). The compleat naturalist. A life of Linnaeus. London: William Collins, Sons \& Company Limited.

Coulton, R. (2020). 'What he hath gather'd together shall not be lost': remembering James Petiver. Notes and Records, 74, 189211. https://doi.org/10.1098/rsnr.2020.0012

Darlington, W. (1849). Memorials of John Bartram and Humphry Marshall, with notices of their botanical contemporaries. Philadelphia: Lindsay \& Blakiston. Retrieved from https://catalog.hathitrust.org/Record/00149 $\underline{3477}$

Franklin, B. (1751). Experiments and observations on electricity, made at Philadelphia in America. London: E. Cave. https://www.gutenberg.org/files/45515/455 15-h/45515-h.htm

Legacies of British Slave-ownership. 2021a. Retrieved from https://www.ucl.ac.uk/lbs/person/view/214 6646777.

Legacies of British Slave-ownership. 2021b. Retrieved from https://www.ucl.ac.uk/lbs/person/view/214 6654787.

Maittaire, M. (1732). Marmorum, arundellianorum, Seldenianorum, aliorumque, academiae Oxoniensi, donatorum; cum variis commentariis \& indice, secunda edition. London: Gulielmi Bowyer. Retrieved from https://books.google.com/books/about/Mar morum Arundellianorum Seldenianorum a.html?id=0JJWxwEACAAJ

Oliver, V. L. (1894). The history of the island of Antigua, one of the Leeward Caribbees in the West Indies. From the first settlement in 1635 to the present time. Vol. 1. London: Mitchell and Hughes. Retrieved from 
https://babel.hathitrust.org/cgi/pt?id=ucbk.a rk: $/ 28722 / \mathrm{h} 2 \mathrm{dq} 4 \mathrm{~m} \&$ view $=1$ up \&seq $=9$

Oliver, V. L. (ed.) (1919). Caribbeana. Being miscellaneous papers relating to the history, genealogy, topography, and antiquities of the British West Indies. Volume III. London: Mitchell, Hughes and Clarke. Retrieved

from

https://babel.hathitrust.org/cgi/pt?id=txu.05 $9173010222637 \&$ view $=1$ up\&seq $=6$

Sloane, H. (1707, 1725). A voyage to the Islands Madera, Barbados, Nieves, S. Christophers and Jamaica, with the natural history of the herbs and trees, four-footed beasts, fishes, birds, insects, reptiles, \&c. of the last of those islands; to which is prefix'd, an introduction, wherein is an account of the inhabitants, air, waters, diseases, trade, \&c. of that place, with some relations concerning the neighbouring continent, and islands of America. Vols. I, II. London. Retrieved from: Vol. I (1707): https://www.biodiversitylibrary.org/item/1 1242\#page/1/mode/1up; Vol. II (1725): https://www.biodiversitylibrary.org/item/1 1241\#page/1/mode/1up

The National Archives, Kew, England (2021). Prerogative court of Canterbury and related probate jurisdictions: will registers; Class: PROB11; Piece: 732.

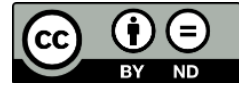

Publisher's note: Eurasia Academic Publishing Group (EAPG) remains neutral with regard to jurisdictional claims in published maps and institutional affiliations.

Open Access This article is licensed under a Creative Commons Attribution-NoDerivatives 4.0 International (CC BY-ND 4.0) licence, which permits copy and redistribute the material in any medium or format for any purpose, even commercially. The licensor cannot revoke these freedoms as long as you follow the licence terms. Under the following terms you must give appropriate credit, provide a link to the license, and indicate if changes were made. You may do so in any reasonable manner, but not in any way that suggests the licensor endorsed you or your use. If you remix, transform, or build upon the material, you may not distribute the modified material.

To view a copy of this license, visit https://creativecommons.org/licenses/by-nd/4.0/. 